Research article

Open Access

\title{
Cytotoxic Sesquiterpene Lactones from Kauna lasiophthalma Griseb
}

\author{
Eliana M. Maldonado ${ }^{1,2}$, Daniel Svensson ${ }^{1}$, \\ Stina M. OREDSSON ${ }^{3}$, Olov STERNER * 1 \\ ${ }^{1}$ Centre for Analysis and Synthesis, Lund University, Getingevägen 60, 221 00, Lund, Sweden. \\ ${ }^{2}$ Centro de Tecnología Agroindustrial, San Simón University, Cochabamba, Bolivia. \\ ${ }^{3}$ Departament of Biology, Lund University, Sölvegatan 35A, 223 62, Lund, Sweden. \\ * Corresponding author. E-mail: Olov.Sterner@chem.lu.se (O. Sterner) \\ Sci Pharm. 2014; 82: 147-160 \\ doi:10.3797/scipharm.1310-18 \\ Published: January $18^{\text {th }} 2014$ \\ Accepted: January $18^{\text {th }} 2014$ \\ Received: $\quad$ October $21^{\text {st }} 2013$ \\ This article is available from: http://dx.doi.org/10.3797/scipharm.1310-18 \\ (c) Maldonado et al.; licensee Österreichische Apotheker-Verlagsgesellschaft m. b. H., Vienna, Austria. \\ This is an Open Access article distributed under the terms of the Creative Commons Attribution License \\ (http://creativecommons.org/licenses/by/3.0/), which permits unrestricted use, distribution, and reproduction \\ in any medium, provided the original work is properly cited.
}

\begin{abstract}
Two new eudesmane derivatives ( $\mathbf{3}$ and $\mathbf{8}$ ) were isolated from the ethanol extract of the aerial parts of Kaunia lasiophthalma Griseb, together with 14 known eudesmane, germacrane, and guaiane sesquiterpenes, and four flavones. The structures and relative configurations of all the compounds were established by NMR spectroscopy and high-resolution mass spectrometry. The anticancer activity of sesquiterpenes 1, 3, 6-9, 11, 12, 14, and 16 was evaluated in vitro with the breast cancer cell lines HCC1937, JIMT-1, L56Br-C1, MCF-7, and SK-BR-3, and compared with the cytotoxicity in the non-cancerous breast epithelial cell line MCF-10A. All compounds were found to possess anticancer activity, and compound $\mathbf{1}$ was the most potent in all of the investigated cancer cell lines with $\mathrm{IC}_{50}$ values ranging between 2.0 and $6.2 \mu \mathrm{M}$. In order to demonstrate the importance of the a-methylene-y-lactone/ester moiety present in all compounds for the effects on the cells, the methyl cysteine adduct $\mathbf{2 1}$ was prepared from $\mathbf{9}$ and found to be inactive or considerably less potent.
\end{abstract}

\section{Keywords}

Kaunia lasiophthalma $\bullet$ Cytotoxicity $\bullet$ Sesquiterpene lactones $\bullet$ Breast cancer cell lines 


\section{Introduction}

The relatively small genus Kaunia (Asteraceae: Eupatorieae) comprises only 14 species of which most grow in Bolivia, but that also are found in Argentina, Brazil, Peru, and Ecuador $[1,2]$. Previous chemical investigations of plants classified in this genus have revealed the presence of sesquiterpene lactones, predominately guaianes, and thymol derivatives as the main constituents [3-5]. Kaunia lasiophthalma Griseb (syn. Eupatorium lasiophthalmum G.) is a shrub bearing white-purple flowers, locally known in Cochabamba, Bolivia by the common name of "Tuwi" and used to treat inflammation and headaches (Lic. Modesto Zárate, personal communication). It has previously been subjected to a phytochemical investigation by Gutierrez and co-workers, who isolated 19 guaiane sesquiterpene lactones [6]. In our search for biologically active compounds in the Bolivian flora, we have isolated and characterized the chemical constituents of the aerial parts of $K$. lasiophthalma G. Two new eudesmanolide derivatives, compounds $\mathbf{3}$ and $\mathbf{8}$, together with 18 known compounds $(\mathbf{1}, \mathbf{2}, \mathbf{4 - 7}, \mathbf{9 - 2 0})$ were obtained, and this constitutes the first report of eudesmanolide and germacranolide sesquiterpenes as well as flavones from this species. As most isolated compounds possess an $\alpha$-methylene- $\gamma$-lactone moiety that previously has been associated with various biological activities, we decided to investigate the effects of the sesquiterpenes available in sufficient quantities on cancer cells. Unsaturated lactones are likely to exert biological effects because they react with cell constituents as Michael acceptors, and have consequently been considered to be generally toxic. However, recent studies have shown that Michael acceptors may be selective and several are currently in clinical trials as drug candidates [7].

Human breast cancer can be classified into different molecular subtypes using gene expression profiles [8-13]. The anticancer activity of compounds $\mathbf{1}, \mathbf{3}, \mathbf{6 - 9}, \mathbf{1 1}, \mathbf{1 2}, \mathbf{1 4}$, and 16 in the five breast cancer cell lines MCF-7 (luminal A subtype), SK-BR-3 (luminal B), HCC1937, L56Br-C1 (basal subtype), and JIMT-1 (HER2 subtype) was compared with the cytotoxicity in the normal-like breast epithelial cell line MCF-10A [8-13]. In breast cancer, each subtype has a different prognosis and is subjected to different treatment. The luminal A and B subgroups express estrogen receptors and are amenable to hormone therapy, while the HER2 group, expressing the human epidermal growth factor receptor 2, may be subjected to trastuzumab therapy. The basal tumors lack expression of both estrogen receptors and HER2; they are biologically more aggressive and the prognosis is often poorer.

\section{Results and Discussion}

The EtOH extract of the leaves and flowers of $K$. lasiophthalma $G$. were subjected, separately, to sequential liquid-liquid partition with hexane, $\mathrm{CH}_{2} \mathrm{Cl}_{2}$, and EtOAc. The major constituents were found to be fats, which were not further investigated, and the compounds reported here are minor metabolites of this plant. Vacuum liquid chromatography (VLC) of the $\mathrm{CH}_{2} \mathrm{Cl}_{2}$ fractions followed by silica gel and Sephadex LH-20 chromatography as well as HPLC fractionation afforded the two new natural products 3 and 8, along with 18 known compounds, 14 sesquiterpenes and four flavonoids (see Figure 1 for chemical structures). 
<smiles>[R]C1C[C@@H]2C(=C)C(=O)O[C@@H]2C=C(C)CC/C=C/1C</smiles>

$1 \mathrm{R}=\mathrm{H}$

$2 \mathrm{R}=\mathrm{OH}$<smiles>[R7]C1([R7])CCC(=C)[C@@H]2[C@@H]3OC(=O)C(=C)[C@H]3CC[C@]21C</smiles>

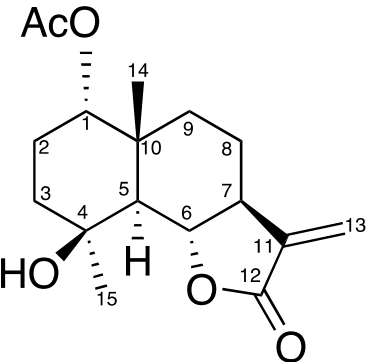

3

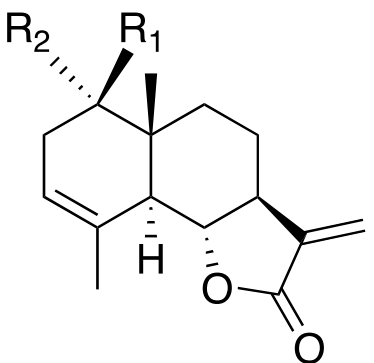

$\begin{array}{ll}\mathbf{R}_{1} & \mathbf{R}_{2}\end{array}$

$9 \mathrm{OH} \quad \mathrm{H}$

$10 \mathrm{H}$ OAc<smiles>[R2]C1([R1])CC[C@@H](O)[C@]2(C)CC[C@H]3C(=C)C(=O)O[C@@H]3[C@H]12</smiles>

$\begin{array}{lll} & \mathbf{R}_{\mathbf{1}} & \mathbf{R}_{\mathbf{2}} \\ \mathbf{4} & \mathrm{Me} & \mathrm{OH} \\ \mathbf{5} & \mathrm{OH} & \mathrm{Me}\end{array}$<smiles>C=C1C(=O)O[C@@H]2C3[C@](C)(CC[C@H]12)C(=O)C=C[C@@]3(C)O</smiles>

11

$R O$,<smiles>C=C1C(=O)O[C@H]2[C@@H]1CCC(C)=C1C[C@@H]3O[C@H]3[C@@]12C</smiles>

$12 \mathrm{R}=\mathrm{Ac}$

$13 \mathrm{R}=\mathrm{iBu}$<smiles>[R]C1=C(C)[C@@H]2C(=C)C(=O)O[C@H]2C(C)=C1C</smiles><smiles>C=C1CC[C@@H](O)[C@]2(C)CC[C@H](C(=C)C(=O)OC)[C@H](O)C12</smiles>

$14 \mathrm{R}=\mathrm{H}$

$15 \mathrm{R}=\mathrm{Cl}$

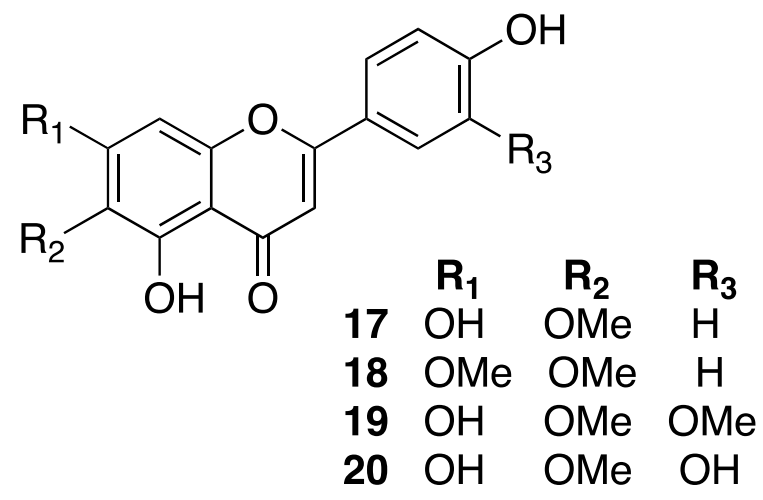<smiles>COC(=O)[C@H](N)CSC[C@H]1C(=O)O[C@@H]2C1CC[C@]1(C)[C@@H](O)CC=C(C)[C@H]21</smiles>

Fig. 1. Structures of the isolated compounds from $K$. lasiophthalma 1-20 and methyl cysteine adduct $\mathbf{2 1}$ 
The known compounds isolated from leaves $(\mathbf{1}, \mathbf{6}, \mathbf{7}, \mathbf{9}, \mathbf{1 0}, \mathbf{1 6}-\mathbf{1 9})$ and flowers (1, 2, 4-7, 9-16, 20) were identified by combined spectroscopic analyses and comparison with literature data, as costunolide (1) [14], haageanolide (2) [15], 1ß-hydroxyarbusculin A (4) [16], 4-epi-1ß-hydroxyarbusculin A (5) [17], reynosin (6) [18], 1-epi-reynosin (7) [19], santamarin (9) [20], the acetate of santamarin (10) [21], 11,13-didehydrovulgarin (11) [22],

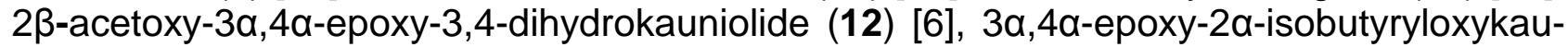
niolide (13) [6], dehydroleucodin (14) [23], 3-chlorodehydroleucodin (15) [6], baynol C (16) [24], hispidulin (17) [25], cirsimaritin (18) [26], jaceosidin (19) [27], and eupafolin (20) [28].

Compound $\mathbf{3}$ was obtained as a colourless gum. The HR-ESI-MS indicated that its elemental composition is $\mathrm{C}_{17} \mathrm{H}_{25} \mathrm{O}_{5}$, which suggests six degrees of unsaturation. The IR spectrum showed absorption bands corresponding to a hydroxyl group $\left(3473 \mathrm{~cm}^{-1}\right)$, an $\alpha$, $\beta$-unsaturated- $y$-lactone function $\left(1764 \mathrm{~cm}^{-1}\right)$, and an ester group $\left(1730 \mathrm{~cm}^{-1}\right)$. The NMR spectra displayed the characteristic signals of an eudesmane lactone, see Table 1 for 1D NMR data and Figure 2 for 2D data. The presence of an exomethylene- $\mathrm{y}$-lactone ring was established by the $13-\mathrm{H}_{2}$ proton signals at $\delta_{\mathrm{H}} 5.94$ and 4.79 and their $\mathrm{HMBC}$ correlations to C-7, C-11, and C-12, and the $6-\mathrm{H}$ lactone proton signal at $\delta_{\mathrm{H}} 3.70$ and its strong ${ }^{1} \mathrm{H}-{ }^{1} \mathrm{H}$ coupling with $7-\mathrm{H}$ and $\mathrm{HMBC}$ correlation to $\mathrm{C}-12$. In addition, the NMR data indicated the presence of the acetoxylated tertiary carbon (C-1) at $\delta_{H} 4.67$ and $\delta_{C} 77.2$ and $\mathrm{HMBC}$ correlations from both $1-\mathrm{H}$ and acetoxy- $\mathrm{H}_{3}$ to the acetoxy carbonyl carbon (C-1'), and an oxygenated quaternary carbon $(\mathrm{C}-4)$ at $\delta_{C} 71.0$. The complete structural elucidation of 3 was achieved by analysis of the HMQC, HMBC, and COSY spectra. The large ${ }^{1} \mathrm{H}-{ }^{1} \mathrm{H}$ coupling constant between $5-\mathrm{H}$ and $6-\mathrm{H}$ and the $\mathrm{HMBC}$ correlations between $14-\mathrm{H}_{3}$ and $\mathrm{C}-1, \mathrm{C}-5, \mathrm{C}-9$, and $\mathrm{C}-10$ links $\mathrm{C}-5$ and the adjacent $\mathrm{Y}$-lactone to the quaternary $\mathrm{C}-10$. COSY correlations from $1-\mathrm{H}$ via $2-\mathrm{H}_{2}$ to $3-\mathrm{H}_{2}$, and $\mathrm{HMBC}$ correlations from $1-\mathrm{H}$ to $\mathrm{C}-5$ and $\mathrm{C}-10$, from $6-\mathrm{H}$ to $\mathrm{C}-4, \mathrm{C}-5, \mathrm{C}-8$, and $\mathrm{C}-10$, as well as from $15-\mathrm{H}_{3}$ to $\mathrm{C}-3, \mathrm{C}-4$, and $\mathrm{C}-5$ close the left cyclohexane ring. The ${ }^{1} \mathrm{H}-{ }^{1} \mathrm{H}$ spin system $5-\mathrm{H} / 6-\mathrm{H} / 7-\mathrm{H} / 8-\mathrm{H}_{2} / 9-\mathrm{H}_{2}$ together with $\mathrm{HMBC}$ correlations from $6-\mathrm{H}$ to $\mathrm{C}-8$ and from $7-\mathrm{H}$ to $\mathrm{C}-9$ close the second cyclohexane ring and establish the eudesmane skeleton unambiguously. The relative configuration of $\mathbf{3}$ was suggested by correlations observed in the NOESY spectrum, from $14-\mathrm{H}_{3}$ to $1-\mathrm{H}, 2 \beta-\mathrm{H}, 3 \beta-\mathrm{H}, 6-\mathrm{H}$, and $8 \beta-\mathrm{H}$, as well as from $5-\mathrm{H}$ to $2 \alpha-\mathrm{H}, 3 \alpha-\mathrm{H}, 7-\mathrm{H}, 8 \alpha-\mathrm{H}$, and $15-\mathrm{H}_{3}$. The proposed configuration is confirmed by the large coupling constants between $5-\mathrm{H}$ and $6-\mathrm{H}$ as well as $6-\mathrm{H}$ and $7-\mathrm{H}$, showing that the three protons are axial, while the small coupling constants between $1-\mathrm{H}$ and $2-\mathrm{H}_{2}$ show that $1-\mathrm{H}$ is equatorial. The comparison of the spectroscopic data of compound $\mathbf{3}$ with those of 4-epi-1 $\beta$ hydroxyarbusculin (5) [17] indicated that they are similar. The difference is that the C-1 hydroxyl group in $\mathbf{5}$ is acetylated in $\mathbf{3}$ and that the configuration at C-1 is inversed, which consequently identifies $\mathbf{3}$ as 4-epi-1 $\alpha$-acetoxy arbusculin A.

Compound 8 was isolated as clear oil. The elemental composition was established by HR-ESI-MS to be $\mathrm{C}_{17} \mathrm{H}_{22} \mathrm{O}_{4}$, indicating seven degrees of unsaturation. The IR spectrum exhibited the presence of an $\alpha, \beta$-unsaturated- $\gamma$-lactone $\left(1770 \mathrm{~cm}^{-1}\right)$ and an ester group $\left(1726 \mathrm{~cm}^{-1}\right)$. The ${ }^{1} \mathrm{H}$ NMR data of 8 are similar to those of the acetate of reynosin [29], the significant differences are the chemical shift of $1-\mathrm{H}$ and $5-\mathrm{H}$ as well as the coupling constants between $1-\mathrm{H}$ and $2-\mathrm{H}_{2}$ which are small in 8 as $1-\mathrm{H}$ is equatorial, but large for the acetate of reynosin as $1-\mathrm{H}$ is axial. An analysis of the NOESY spectrum of $\mathbf{8}$ showed correlations from $14-\mathrm{H}_{3}$ to $1-\mathrm{H}, 2 \beta-\mathrm{H}, 6-\mathrm{H}, 8 \beta-\mathrm{H}$, and $9 \beta-\mathrm{H}$ as well as from $5-\mathrm{H}$ to $3 \alpha-\mathrm{H}$, 7-H, and $8 \alpha-\mathrm{H}$. Therefore, compound 8 was identified as acetyl 1-epi-reynosin. 
The anticancer activities of sesquiterpenes 1, 3, 6-9, 11, 12, 14, and 16 were assessed in five breast-cancer cell lines, HCC1937, JIMT-1, L56Br-C1, MCF-7, and SK-BR-3, and compared with the cytotoxicity in the breast-derived non-cancerous cell line MCF-10A using the MTT colorimetric assay. The inhibitory concentration 50 values $\left(\mathrm{IC}_{50}\right)$ were deduced from the obtained dose-response curves and are presented in Table 2. Interestingly, the cancer cell lines were more sensitive to all of the compounds than the normal-like MCF-10A cells. No obvious patterns related to the breast cancer cell line subgroup (vide supra) was found, and all compounds possessed activity. Compound 1 was found to be the most active in all of the cell lines with $I_{50}$ values ranging from 2.0 to $6.2 \mu \mathrm{M}$ in the cancer cell lines, while compounds 3 and 16 exhibited the lowest activity. 16 is an unsaturated ester and differs in that respect from the other compounds, but the lower activity of $\mathbf{3}$ compared to the similar compounds was unexpected. Costunolide (1) differs from the eudesmane sesquiterpenes by having the unsaturated lactone fused with a macrocyclic system instead of a cyclohexane ring, and the tension of the lactone ring is likely to be lower in $\mathbf{1}$. This would render 1 less reactive and possibly more selective. Indeed, 1 together with the two guaianes 12 and 14, shows a slightly higher selectivity for the cancer cells compared to the eudesmanes. The difference in the activities of $\mathbf{7}$ and $\mathbf{8}$ may depend on the higher lipophilicity of $\mathbf{8}$, facilitating its absorption into the cells. In $\mathbf{1 1}$ and 14, the presence of a second Michael acceptor function may influence the activity. It is difficult to speculate from these data, but a trend is that the MCF-7 cells seem slightly less affected than the other cancer cell lines. MCF-7 has a normal wild type $p 53$ gene, which the MCF-10A cells also have, while the others have a mutated $p 53$. Thus, MCF-7 and MCF-10A cells may share a property of being blocked in the $G_{1}$ phase of the cell cycle, which has a protective function, while the other cancer cell lines do not.

Previous investigations of sesquiterpenoid a-methylene- $y$-lactones have indicated that the cytotoxic and antitumor activities are related to their ability to react as Michael acceptors [7]. We therefore added methyl cysteine to the exocyclic methylene group of $\mathbf{9}$ to give $\mathbf{2 1}$, and compared its cytotoxicity with the natural products'. As can be seen from the results in Table 2, 21 is significantly less potent, however, it is not devoid of activity and its cytotoxicity towards the normal-like MCF-10A cells is similar to that of the a-methylene-y-lactones. This may depend on the reversibility of Michael additions, by which 21 slowly can eliminate methyl cysteine and regenerate $\mathbf{9}$ during the assay conditions [7].
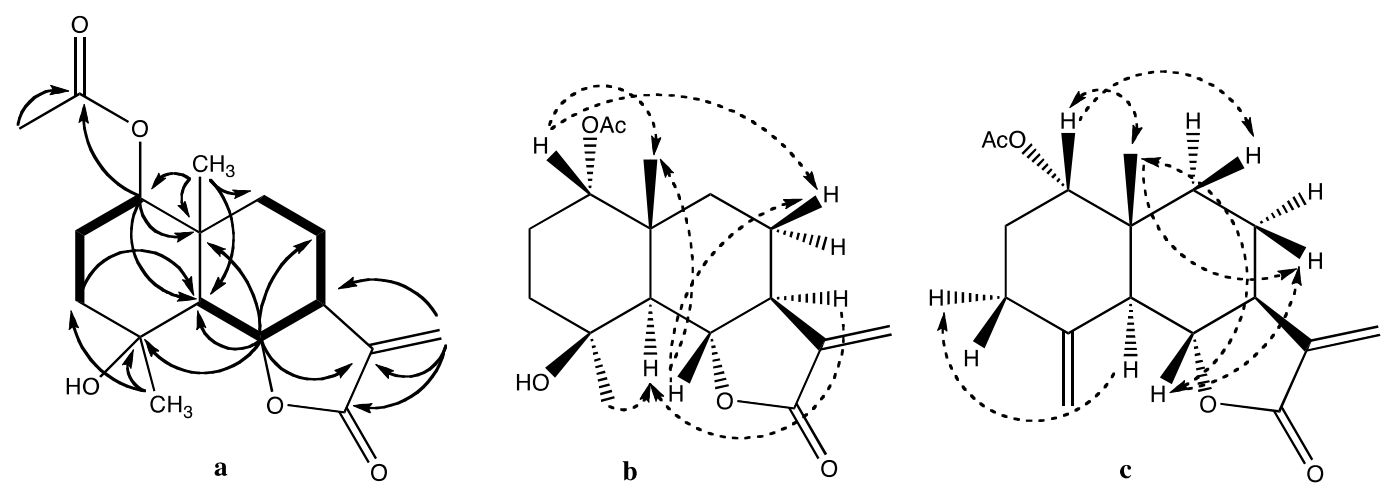

Fig. 2. (a) Important $\mathrm{HMBC}$ (arrow) and ${ }^{1} \mathrm{H}-{ }^{1} \mathrm{H}$ COSY (bold) correlations for 3

(b) and (c) Key NOESY correlations for $\mathbf{3}$ and $\mathbf{8}$, respectively 
In conclusion, the molecular causes for the lower cytotoxicity of the compounds (especially compound 1) in the normal-like breast epithelial MCF-10A compared to the breast cancer cells lines need to be further exploited and may find clinical use by showing less off-target cytotoxicity.

Tab. 1. ${ }^{1} \mathrm{H}$ and ${ }^{13} \mathrm{C}$ NMR data of compounds $3\left(\mathrm{C}_{6} \mathrm{D}_{6}\right)$ and $8\left(\mathrm{CDCl}_{3}\right)$

\begin{tabular}{|c|c|c|c|c|}
\hline \multirow{2}{*}{ Position } & \multicolumn{2}{|l|}{3} & \multicolumn{2}{|l|}{8} \\
\hline & ${ }^{1} \mathrm{H}(\mathrm{J}, \mathrm{Hz})$ & ${ }^{13} \mathrm{C}$ & ${ }^{1} \mathrm{H}(\mathrm{J}, \mathrm{Hz})$ & ${ }^{13} \mathrm{C}$ \\
\hline 1 & $4.67 \mathrm{br} d d(2,2)$ & 77.2 & 4.68 br dd $(2,3)$ & 76.4 \\
\hline $2 \beta$ & 1.99 dddd $(13,13,4.5,2.2)$ & 23.0 & 1.86 dddd $(13.9,13.4,5.1,2.7)$ & 27.1 \\
\hline $2 \alpha$ & $1.53 \mathrm{~m}$ & & $1.81 \mathrm{~m}$ & \\
\hline $3 \beta$ & $1.15 \mathrm{~m}$ & $36.2^{\star}$ & 2.20 ddd $(13.5,5.1,1.9)$ & 30.5 \\
\hline $3 a$ & $1.53 \mathrm{~m}$ & & 2.32 ddd $(13.5,13.4,5.4)$ & \\
\hline 4 & - & 71.0 & - & 143.2 \\
\hline 5 & $1.57 \mathrm{~d}(11.2)$ & 50.5 & $2.79 \mathrm{~d}(11.0)$ & 48.7 \\
\hline 6 & $3.70 \mathrm{dd}(11,11)$ & 79.8 & $4.00 \mathrm{dd}(11,11)$ & 79.8 \\
\hline 7 & $1.76 \mathrm{~m}$ & 50.7 & 2.55 ddddd $(12,11,3,3,3.4)$ & 49.3 \\
\hline $8 \beta$ & $1.26 \mathrm{~m}$ & 21.4 & 1.61 dddd $(12,12,11,3.4)$ & 21.2 \\
\hline $8 \alpha$ & $1.03 \mathrm{~m}$ & & $2.08 \mathrm{~m}$ & \\
\hline $9 \beta$ & $0.84 \mathrm{~m}$ & $36.2^{*}$ & 1.42 ddd $(13.0,2.8,3.2)$ & 33.1 \\
\hline $9 \alpha$ & 1.24 br ddd $(14,14,4)$ & & 1.72 ddd $(13.0,13.0,4.0)$ & \\
\hline 10 & - & 40.7 & - & 41.7 \\
\hline 11 & - & 140.4 & - & 139.1 \\
\hline 12 & - & 170.0 & - & 170.5 \\
\hline \multirow[t]{2}{*}{13} & $5.94 \mathrm{~d}(3.2)$ & 115.9 & $6.09 \mathrm{~d}(3.2)$ & 117.0 \\
\hline & $4.79 \mathrm{~d}(3.2)$ & & $5.40 \mathrm{~d}(3.2)$ & \\
\hline 14 & $0.92 \mathrm{~s}$ & 20.0 & $0.92 \mathrm{~s}$ & 18.0 \\
\hline 15 & $1.29 \mathrm{~s}$ & 32.9 & 5.00 br s & 110.2 \\
\hline & & & 4.87 br s & \\
\hline $1^{\prime}$ & - & 169.7 & - & 170.4 \\
\hline $2^{\prime}$ & $1.74 \mathrm{~s}$ & 21.1 & $2.12 \mathrm{~s}$ & 21.2 \\
\hline
\end{tabular}

\section{Experimental}

\section{General}

Optical rotations were measured with a Perkin Elmer Model 341 polarimeter. IR spectra were recorded with a Bruker Alpha-P FT-IR instrument in the ATR geometry with a diamond ATR unit. HR-ESI-MS was performed with a Waters Q-TOF Micro system spectrometer (using $\mathrm{H}_{3} \mathrm{PO}_{4}$ for calibration and as internal standard). 1D and 2D NMR spectra were recorded at room temperature on the Bruker Avance II $400 \mathrm{MHz}$ and Bruker Avance $500 \mathrm{MHz}$ spectrometers, operating at 400 and $500 \mathrm{MHz}$ for ${ }^{1} \mathrm{H}$ and 100 and 125 $\mathrm{MHz}$ for ${ }^{13} \mathrm{C}$, respectively. The chemical shifts $(\delta)$ are reported in ppm relative to solvent signals $\delta_{\mathrm{H}} 7.16$ and $\delta_{\mathrm{C}} 128.39$ for $\mathrm{C}_{6} \mathrm{D}_{6}$, and $\delta_{\mathrm{H}} 7.26$ and $\delta_{\mathrm{C}} 77.00$ for $\mathrm{CDCl}_{3}$, while the coupling constants $(\mathrm{J})$ are given in $\mathrm{Hz}$. Vacuum liquid chromatography (VLC) separations 
were carried out on the Merck Silica gel 60G (Merck), while column chromatography (CC) was performed using the Silica gel 60 (230-400 mesh, Merck), silver nitrate-impregnated Silica gel 60 [30], and gel permeation on Sephadex LH-20 (GE Healthcare). TLC analyses were carried out using aluminium-backed silica gel $60 \mathrm{~F}_{254}(0,2 \mathrm{~mm}$ thickness, Merck). Chromatograms were visualized under a UV lamp at $254 \mathrm{~nm}$ then sprayed with vanillin and $\mathrm{KMnO}_{4} / \mathrm{K}_{2} \mathrm{CO}_{3} / \mathrm{NaOH}$ solution followed by heating. Preparative TLC (PTLC) was run on $20 \times 20 \mathrm{~cm}$ glass-coated plates (1 mm thickness, Analtech) and doped TLC plates in $\mathrm{MeCN}: \mathrm{AgNO}_{3}$ solution [31]. HPLC was performed on the Agilent 1260 Infinity Quaternary LC system, equipped with a Standard Autosampler (G1329B), Thermostated Column Compartment (G1316A TCC), a Diode Array Detector VL (G1315D), and a semipreparative column (XTerra RP18, 10x150 mm, $5 \mu \mathrm{m}$ i.d, Waters).

Tab. 2. Cytotoxicity $\left(\mathrm{IC}_{50}\right.$ in $\left.\mu \mathrm{M}\right)$ of compounds $1,3,6-9,11,12,14,16$, and 21

\begin{tabular}{lcccccc}
\hline Comp. & $\begin{array}{c}\text { HCC1937 } \\
\boldsymbol{M M}\end{array}$ & $\begin{array}{c}\text { JIMT-1 } \\
\boldsymbol{M M}\end{array}$ & $\begin{array}{c}\text { L56Br-C1 } \\
\boldsymbol{M M}\end{array}$ & $\begin{array}{c}\text { MCF-7 } \\
\boldsymbol{M M}\end{array}$ & $\begin{array}{c}\text { SK-BR-3 } \\
\boldsymbol{M M}\end{array}$ & $\begin{array}{c}\text { MCF-10A } \\
\mu \mathrm{M}\end{array}$ \\
\hline 1 & $2.2 / 4.2^{\mathrm{b}}$ & $6.2 / 6.3^{\mathrm{b}}$ & $3.7 / 4.8^{\mathrm{b}}$ & $5.3 \pm 1.4^{\mathrm{c}}$ & $2.0 \pm 1.0^{\mathrm{c}}$ & $20.0^{\mathrm{a}}$ \\
3 & $23.0^{\mathrm{a}}$ & $18.0^{\mathrm{a}}$ & $9.3^{\mathrm{a}}$ & $27.0^{\mathrm{a}}$ & $10.1^{\mathrm{a}}$ & $38.0^{\mathrm{a}}$ \\
6 & $10.0^{\mathrm{a}}$ & $8.5 / 12.0^{\mathrm{b}}$ & $11.0^{\mathrm{a}}$ & $16.4 \pm 7.1^{\mathrm{c}}$ & $5.2 \pm 1.6^{\mathrm{c}}$ & $17.0^{\mathrm{a}}$ \\
7 & $12.0 / 18.5^{\mathrm{b}}$ & $12.0 / 14.0^{\mathrm{b}}$ & $9.0 / 10.1^{\mathrm{b}}$ & $23.0 / 30.0^{\mathrm{b}}$ & $7.6 / 6.4^{\mathrm{b}}$ & $22.0^{\mathrm{a}}$ \\
8 & $3.2 / 7.5^{\mathrm{b}}$ & $6.3 / 7.0^{\mathrm{b}}$ & $8.4 / 12.0^{\mathrm{b}}$ & $11.0 \pm 1.7^{\mathrm{c}}$ & $4.7 \pm 1.1^{\mathrm{c}}$ & $24.0^{\mathrm{a}}$ \\
9 & $8.1 \pm 1.8^{\mathrm{c}}$ & $6.9 / 7.2^{\mathrm{b}}$ & $12.3 \pm 5.5^{\mathrm{c}}$ & $9.7 \pm 0.9^{\mathrm{c}}$ & $3.1 \pm 0.6^{\mathrm{c}}$ & $17.0^{\mathrm{a}}$ \\
11 & $4.8 / 7.8^{\mathrm{b}}$ & $10.0 / 13.0^{\mathrm{b}}$ & $3.6^{\mathrm{a}}$ & $10.1 / 18.0^{\mathrm{b}}$ & $4.2 \pm 2.1^{\mathrm{c}}$ & $24.0 / 21.0^{\mathrm{b}}$ \\
12 & $6.0 / 7.8^{\mathrm{b}}$ & $7.1 / 10.1^{\mathrm{b}}$ & $6.0 / 10.1^{\mathrm{b}}$ & $7.1 / 8.3^{\mathrm{b}}$ & $4.2 \pm 1.1^{\mathrm{c}}$ & $17.0 / 38.0^{\mathrm{b}}$ \\
14 & $3.0 / 5.2^{\mathrm{b}}$ & $7.5 / 8.1^{\mathrm{b}}$ & $5.8 / 10.0^{\mathrm{b}}$ & $3.3 / 4.3^{\mathrm{b}}$ & $2.5 \pm 0.4^{\mathrm{c}}$ & $20.0 / 23.0^{\mathrm{b}}$ \\
16 & $24.0^{\mathrm{a}}$ & $13.0 / 23.0^{\mathrm{b}}$ & $16.0^{\mathrm{a}}$ & $27.4 \pm 17.2^{\mathrm{c}}$ & $9.9 \pm 3.0^{\mathrm{c}}$ & $29.0^{\mathrm{a}}$ \\
21 & $100.0^{\mathrm{a}}$ & $>100$ & $73.0^{\mathrm{a}}$ & $>100$ & $51.0 / 40.0^{\mathrm{b}}$ & $41.0^{\mathrm{a}}$ \\
\hline
\end{tabular}

Values from: ${ }^{a}$ one dose-response curve, ${ }^{b}$ two dose-response curves, ${ }^{c}$ three or more dose-response curves.

\section{Plant Material}

The aerial parts of Kaunia lasiophthalma (Griseb) R.M. King and H. Robinson were collected on September 5th, 2009, near Independencia, Cochabamba, Bolivia, at coordinates 17\%11.10' S 66 $43.58^{\prime} \mathrm{W}$ and an elevation of $2943 \mathrm{~m}$, during the flowering period. This aromatic herbaceous plant can grow up to $4 \mathrm{~m}$ in height and bears white-purple flowers. Lic. Modesto Zárate did the authentication, and voucher specimens have been deposited at Herbario Forestal Martín Cárdenas, Cochabamba (accession number MZ-3948).

\section{Extraction and Isolation}

The air-dried and ground leaves (788.5 g) and flowers (1064.0 g) were extracted separately by maceration with $95 \% \mathrm{EtOH}$ for 24 hours, two times at room temperature. After filtration, the combined extracts were concentrated under reduced pressure and the following crude extracts were obtained: $90.0 \mathrm{~g}$ from leaves and $91.0 \mathrm{~g}$ from flowers.

\section{Leaves}

The crude organic extract $(90.0 \mathrm{~g})$ was suspended in a mixture of $\mathrm{H}_{2} \mathrm{O}: \mathrm{MeOH}(9: 1, \mathrm{v} / \mathrm{v}$, 
$500 \mathrm{ml}$ ) and partitioned between hexane (four times, 1:1, v/v), $\mathrm{CH}_{2} \mathrm{Cl}_{2}$ (two times, 1:1, v/v), and EtOAc (one time, 1:1, v/v). After evaporation of the solvent, the extracts weighed $22.68,33.83$, and $7.24 \mathrm{~g}$, respectively. Subjection of the $\mathrm{CH}_{2} \mathrm{Cl}_{2}(18.7 \mathrm{~g})$ to VLC (PE:EtOAc 1:0 to 0:1) gave four major fractions (A-D) based on TLC analyses. Purification of fraction $B(10.8 \mathrm{~g})$, using open $\mathrm{CC}\left(\mathrm{PE}: \mathrm{CH}_{2} \mathrm{Cl}_{2}\right.$ 1:0 to $0: 1 ; \mathrm{CH}_{2} \mathrm{Cl}_{2}$ : EtOAC 1:1) yielded nine fractions (B1-B9). Fraction B5 (579.6 mg) was chromatographed by flash CC (heptane: $\mathrm{Me}_{2} \mathrm{CO} 98: 2$ to 88:12) and combined into 13 fractions according to its TLC profile (B5.1-B5.13). Stigmasterol (52.4 mg) and 1 (35.6 mg) were obtained pure from B5.1 and B5.3, respectively. Further purification of $\mathrm{B} 5.6\left(80.0 \mathrm{mg}\right.$ ) by $\mathrm{CC}$ (heptane: $\mathrm{Et}_{2} \mathrm{O} 100: 0$ to 95:5) and Sephadex LH-20 (MeOH) afforded 10 (6.3 mg) and 8 (32.9 mg). Fraction B7 $(2.64 \mathrm{~g})$ was applied on the Sephadex $\mathrm{LH}-20 \mathrm{CC}(\mathrm{MeOH})$ to give six fractions (B7.1-B7.6). B.7.4 (631.0 $\mathrm{mg})$ and B8 (948.6 $\mathrm{mg})$ were submitted to chromatography on the Sephadex $\mathrm{LH}-20 \mathrm{CC}(\mathrm{MeOH})$ to give $16(46.1 \mathrm{mg})$ after recrystallization in MeOH. Fraction B7.5 (316.0 mg) and B7.7 (153.7 mg) were sequentially purified by the Sephadex LH-20 (MeOH), CC (PE:EtOAC 1:0 to 8:2), and PTLC (PE:EtOAc 6:4) giving 3 (1.7 mg) and 7 $(18.9 \mathrm{mg})$, respectively. Fraction $\mathrm{B} 9(956.8 \mathrm{mg})$ was fractionated by $\mathrm{CC}$ (heptane:Me $\mathrm{MCO}_{2}$ 9:1) affording nine fractions (B9.1-B9.9). Each individual fraction B9.3 (139.4 mg) and B9.4 (470.0 mg) were further purified by the Sephadex LH-20 CC (MeOH) followed by CC (PE:EtOAc 1:0 to 8:2) to obtain $6(10.0 \mathrm{mg})$ and $9(80.0 \mathrm{mg})$. Compound $17(59.0 \mathrm{mg})$ was recrystallized in $\mathrm{CH}_{2} \mathrm{Cl}_{2}$ : $\mathrm{MeOH}$ from $\mathrm{B} 9.6$ (120.0 mg). Fraction $\mathrm{C}(589.0 \mathrm{mg})$ was separated by the Sephadex $\mathrm{LH}-20 \mathrm{CC}(\mathrm{MeOH})$ to yield seven fractions (C1-C7). A mixture $1: 1$ of compounds 18 and $19(26.0 \mathrm{mg})$ were obtained from C7 (330.0 mg).

\section{Flowers}

The flower extract $(75.8 \mathrm{~g})$ was partitioned as described above to yield the corresponding hexane $(30.19 \mathrm{~g}), \mathrm{CH}_{2} \mathrm{Cl}_{2}(26.52 \mathrm{~g})$, and EtOAc $(2.13 \mathrm{~g})$ fractions, respectively. The $\mathrm{CH}_{2} \mathrm{Cl}_{2}$ fraction $(24.0 \mathrm{~g}$ ) was subjected to VLC (PE:EtOAc 1:0 to 0:1) and combined according to its TLC profile into nine fractions $(\mathrm{A}-\mathrm{H})$. Fraction $\mathrm{B}(1.23 \mathrm{~g})$, containing mostly 1, was dissolved in heptane:MeOH, filtered, concentrated, and recrystallized from heptane: $\mathrm{Me}_{2} \mathrm{CO}$ to afford pure $1(318.0 \mathrm{mg})$. Fraction $\mathrm{C}(633.0 \mathrm{mg})$ was subjected to VLC (PE:EtOAc 1:0 to 0:1) to yield 11 fractions (C1-C11). C3 (360.0 mg) was dissolved in PE and centrifuged to obtain $10(8.0 \mathrm{mg})$ as a white powder. The liquid residue was chromatographed by $\mathrm{CC}\left(\mathrm{PE}: \mathrm{Et}_{2} \mathrm{O} \quad 1: 0\right.$ to 2:3) giving eight fractions (C3.1-C3.8). Compound $8(4.5 \mathrm{mg})$ was obtained from C3.5 $(29.0 \mathrm{mg})$ by recrystallization from hexane: $\mathrm{CH}_{2} \mathrm{Cl}_{2}$ and 13 (2.7 mg) from C3.8 (17.8 mg) by HPLC (MeOH: $\mathrm{H}_{2} \mathrm{O} 3: 7, \mathrm{t}_{\mathrm{R}}=13.5$ $\min , 240 \mathrm{~nm}, 1 \mathrm{ml} / \mathrm{min})$. Subjection of fraction $\mathrm{D}(1.78 \mathrm{~g})$ to VLC (PE:Et $2 \mathrm{O} 1: 0$ to 0:1) afforded six fractions (D1-D6). Compound $12(173.0 \mathrm{mg})$ was purified from D4 (390.0 mg) and D5 $(386.0 \mathrm{mg})$ by recrystallization from heptane: $\mathrm{Me}_{2} \mathrm{CO}$. The liquid residue $(232.0 \mathrm{mg})$ was subjected to flash CC (heptane: $\left.\mathrm{CH}_{2} \mathrm{Cl}_{2}: \mathrm{Me}_{2} \mathrm{CO} 10: 10: 1\right)$ to produce 7 (23.3 mg). D6 (470.0 mg) was applied to the Sephadex LH-20 CC (MeOH) to give $14(36.0 \mathrm{mg})$. E (270.0 $\mathrm{mg}$ ) was fractionated by VLC (heptane: $\mathrm{Me}_{2} \mathrm{CO} 1: 0$ to $5: 1$ ) to give seven fractions (E1-E7). E3 (151.0 mg) and E4 (642.0 mg) were combined and separated by flash CC (Silica gel doped with $10 \% \mathrm{AgNO}_{3} \mathrm{w} / \mathrm{w}, \mathrm{PE}: \mathrm{Et}_{2} \mathrm{O}: \mathrm{Me}_{2} \mathrm{CO}$ 5:5:1) to yield 9 (96.0 mg) and 6 (32.0 mg) as white needles. Sequential purification of E5 (1.02 g) was achieved by the Sephadex $\mathrm{LH}-20\left(\mathrm{CHCl}_{3}: \mathrm{MeOH}\right.$ 1:1) and CC (heptane: $\mathrm{CH}_{2} \mathrm{Cl}_{2}: \mathrm{Me}_{2} \mathrm{CO}$ 2:17:1) to yield 15 (1.1 mg), 14 (16.0 mg), $9(37.0 \mathrm{mg})$, and $7(10.0 \mathrm{mg})$. Fraction $\mathrm{F}(1.53 \mathrm{~g})$ was applied to VLC (hexane: $\mathrm{Et}_{2} \mathrm{O}$ 20:1, 1:3; hexane:Me ${ }_{2} \mathrm{CO}$ 99:1, 80:20) yielding 12 fractions (F1-F12). The $\mathrm{CH}_{2} \mathrm{Cl}_{2}$ soluble part of $\mathrm{F} 4(194.0 \mathrm{mg})$ was purified by $\mathrm{VLC}\left(\mathrm{CH}_{2} \mathrm{Cl}_{2}: \mathrm{Me}_{2} \mathrm{CO}\right.$ 1:0 to $\left.4: 1\right)$ 
giving three fractions (F4.1-F4.3). Each fraction was further purified to afford 11 (10.0 mg), $2(2.9 \mathrm{mg})$, and $16(4.7 \mathrm{mg})$, respectively. Repeated purification of G (950.0 $\mathrm{mg})$ by VLC $\left(\mathrm{CH}_{2} \mathrm{Cl}_{2}: \mathrm{Me}_{2} \mathrm{CO} 98: 2\right.$ to 0:1) and flash $\mathrm{CC}\left(\mathrm{CH}_{2} \mathrm{Cl}_{2}: \mathrm{Me}_{2} \mathrm{CO}\right.$ 9:1) afforded 4 (10.1 $\left.\mathrm{mg}\right)$ by recrystallization from heptane: $\mathrm{Me}_{2} \mathrm{CO}$. Fraction I $(4.9 \mathrm{mg})$ was subjected to $\mathrm{CC}$ $\left(\mathrm{CH}_{2} \mathrm{Cl}_{2}: \mathrm{Me}_{2} \mathrm{CO} 6: 4\right.$ to $\left.0: 1\right)$ yielding seven fractions (I1-I7). Sequential purification of I3 $(1.06 \mathrm{~g})$ by the Sephadex $\mathrm{LH}-20\left(\mathrm{CHCl}_{3}: \mathrm{MeOH} 1: 1\right)$ and $\mathrm{CC}\left(\mathrm{CH}_{2} \mathrm{Cl}_{2}: \mathrm{Me}_{2} \mathrm{CO} 6: 4\right.$ to 0:1) produced 5 (9.7 $\mathrm{mg})$ and $20(2.5 \mathrm{mg})$.

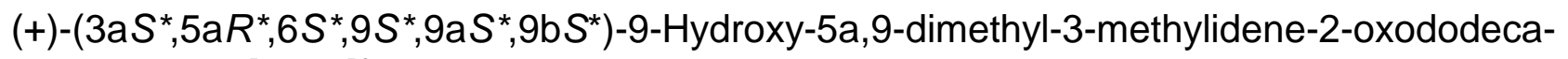
hydronaphtho[1,2-b]furan-6-yl acetate

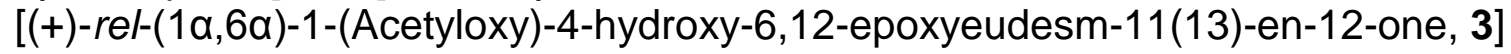

Colourless gum; $[\alpha]_{D}^{25}+70.8\left(c\right.$ 0.4, $\left.\mathrm{CHCl}_{3}\right)$; IR $v_{\max }\left(\mathrm{cm}^{-1}\right) 3473,2933,2865,2359,2342$, $1764,1730,1375,1246,1197,1134,1018,966 ;{ }^{1} \mathrm{H}\left(500 \mathrm{MHz}, \mathrm{C}_{6} \mathrm{D}_{6}\right)$, and ${ }^{13} \mathrm{C}(125 \mathrm{MHz}$, $\mathrm{C}_{6} \mathrm{D}_{6}$ ) see Table 1; HR-ESI-MS m/z $309.1722[\mathrm{M}+\mathrm{H}]^{+}$(calcd. for $\mathrm{C}_{17} \mathrm{H}_{25} \mathrm{O}_{5}$ 309.1702).

$\left(3 a S^{\star}, 5 a R^{\star}, 6 S^{\star}, 9 a S^{\star}, 9 \mathrm{~b} S^{\star}\right)$-5a-Methyl-3,9-dimethylidene-2-oxododecahydronaphtho[1,2-b]furan-6-yl acetate

[(+)-rel-(1a,6a)-1-(Acetyloxy)-6,12-epoxyeudesma-4(14),11(13)-dien-12-one, 8]

Colourless oil; $[\alpha]_{\mathrm{D}}{ }^{25}+170.4\left(c \mathrm{c} 0.3, \mathrm{CHCl}_{3}\right)$; IR $v_{\max }\left(\mathrm{cm}^{-1}\right)$ 2942, 1769, 1726, 1372, 1240, $1174,1121,1039,1016,969 .{ }^{1} \mathrm{H}\left(500 \mathrm{MHz}, \mathrm{CDCl}_{3}\right)$, and ${ }^{13} \mathrm{C}\left(125 \mathrm{MHz}, \mathrm{CDCl}_{3}\right)$ see Table 1; HR-ESI-MS m/z 291.1613 [M + H] $]^{+}$(calcd. for $\mathrm{C}_{17} \mathrm{H}_{22} \mathrm{O}_{4}$ 291.1596).

\section{Preparation of Compound 21}

$10.0 \mathrm{mg}(0.04 \mathrm{mmol})$ of 9 and $8.3 \mathrm{mg}(0.048 \mathrm{mmol})$ methyl-L-cysteine ester hydrochloride were dissolved in methanol $(1 \mathrm{~mL})$ and the mixture was heated at $60^{\circ} \mathrm{C}$ and stirred. After $48 \mathrm{~h}, 1.6 \mathrm{mg}(0.0093 \mathrm{mmol})$ methyl-L-cysteine ester was added and the reaction mixture was left for another $24 \mathrm{~h}$. Then, the solvent was evaporated under reduce pressure and the dry residue dissolved in $\mathrm{H}_{2} \mathrm{O}(3 \mathrm{~mL})$, and washed with $\mathrm{CHCl}_{3}(3 \times 1.5 \mathrm{~mL})$. The organic phase dried in vacuo yielded $15.5 \mathrm{mg}$ of a yellow residue, which was purified by the Sephadex $\mathrm{LH}-20\left(\mathrm{CHCl}_{3}: \mathrm{MeOH} 1: 1\right)$ to give $8.0 \mathrm{mg}(0.021 \mathrm{mmol})$ of 21 as yellow oil. ${ }^{1} \mathrm{H}$ NMR (400 MHz, CD $\left.{ }_{3} \mathrm{OD}\right)$ : $\delta 5.35(\mathrm{~m}, 1 \mathrm{H}), 4.12(\mathrm{t}, \mathrm{J}=11.0 \mathrm{~Hz}, 1 \mathrm{H}), 3.75(\mathrm{~s}, 3 \mathrm{H}), 3.69(\mathrm{~m}$, $1 \mathrm{H}), 3.59(\mathrm{~m}, 1 \mathrm{H}), 3.00(\mathrm{~m}, 1 \mathrm{H}), 2.94(\mathrm{~m}, 1 \mathrm{H}), 2.88(\mathrm{~m}, 1 \mathrm{H}), 2.84(\mathrm{~m}, 1 \mathrm{H}), 2.76(\mathrm{~m}, 1 \mathrm{H})$, $2.28(\mathrm{~m}, 1 \mathrm{H}), 1.98(\mathrm{~m}, 1 \mathrm{H}), 1.96(\mathrm{~m}, 1 \mathrm{H}), 1.95(\mathrm{~m}, 2 \mathrm{H}), 1.76(\mathrm{~s}, 3 \mathrm{H}), 1.66(\mathrm{~m}, 2 \mathrm{H}), 1.26(\mathrm{~m}$, 1H), 0.89 (s, 3H). ${ }^{13} \mathrm{C}\left(100 \mathrm{MHz}, \mathrm{CD}_{3} \mathrm{OD}\right): \delta 179.5$ (C-12), 175.4 (C-3'), 134.7 (C-4), 122.7 (C-3), 82.8 (C-6), 75.9 (C-1), 55.0 (C-2'), 52.7 (C-4'), 52.2 (C-5), 51.8 (C-11), 47.0 (C-7), 41.9 (C-10), 38.6 (C-1'), 35.9 (C-9), 33.5 (C-2), 31.6 (C-13), 24.1 (C-8), 23.6 (C-15), 11.3 (C-14). HR-ESI-MS m/z $406.1703[\mathrm{M}+\mathrm{Na}]+$ (calcd. for $\mathrm{C}_{19} \mathrm{H}_{29} \mathrm{NO}_{5} \mathrm{SNa}$ 406.1664).

\section{Biological Assay}

\section{Cell Culture}

The L56Br-C1 cell line was established at the Department of Oncology, Clinical Sciences, Lund University, Sweden [32]. The JIMT-1 cell line was purchased from the German Collection of Microorganisms and Cell Cultures (Braunschweig, Germany) and the MCF-7, SK-BR-3, HCC1937, and MCF-10A cells were obtained from the American Tissue Type Culture Collection (Manassas, VA, USA). The cell lines were cultured as monolayers at $37^{\circ} \mathrm{C}$ in a humidified incubator with $5 \% \mathrm{CO}_{2}$ in air. The MCF-10A cells have a population 
doubling time of 15 hours, the JIMT-1 cells 24 hours, and the other four cell lines around 35 hours.

The L56Br-C1, MCF-7, SK-BR-3, and HCC1937 cells were cultured as described by Holst et al [33]. JIMT-1 cells were cultured in DMEM/Ham's F12 medium supplemented with $10 \%$ fetal calf serum, non-essential amino acids $(1 \mathrm{mM})$, insulin $(10 \mu \mathrm{g} / \mathrm{ml})$, penicillin $(100 \mathrm{U} / \mathrm{ml})$, and streptomycin $(100 \mu \mathrm{g} / \mathrm{ml})$. MCF-10A cells were maintained in RPMI 1640 medium supplemented with $10 \%$ heat-inactivated fetal calf serum, non-essential amino acids $(1 \mathrm{mM})$, insulin $(10 \mu \mathrm{g} / \mathrm{ml})$, epidermal growth factor $(20 \mathrm{ng} / \mathrm{ml})$, cholera toxin $(50 \mathrm{ng} / \mathrm{ml})$, hydrocortisone $(250 \mathrm{ng} / \mathrm{ml})$, penicillin $(100 \mathrm{U} / \mathrm{ml})$, and streptomycin $(100 \mu \mathrm{g} / \mathrm{ml})$. The MCF-10A and JIMT-1 cell lines were sub-cultured twice a week, while the L56Br-C1, MCF-7, SK-BR-3, and HCC1937 cells were sub-cultured once a week with an additional change of growth medium once a week.

\section{Dose-Response Assay}

Stock solutions (10 or $100 \mu \mathrm{M}$ ) of the compounds were made in $100 \%$ DMSO. These were further diluted in PBS to obtain the correct concentrations used for the MTT assay. Appropriate DMSO controls were used. In general, the highest DMSO concentration was $0.1 \%$, however, when treating with $100 \mu \mathrm{M}$ and starting from a $10 \mu \mathrm{M}$ stock in $100 \%$ DMSO, a final concentration of $1 \%$ DMSO was used as the control.

The MTT assay was performed as previously described [34]. Briefly, the cells were trypsinized and counted in a hemocytometer. Aliquots of $180 \mu \mathrm{l}$ cell suspensions containing 3000 (MCF-10A) and 6000 (MCF-7, SK-BR-3, JIMT-1, L56Br-C1, and HCC1937) cells were seeded in the wells of 96-well plates. Compounds were added 24 hours after seeding to allow the attachment of cells. A concentration range between 0.1 to $100 \mu \mathrm{M}$ was used in the MTT assays and appropriate DMSO controls. At $72 \mathrm{~h}$ of drug treatment, $20 \mu \mathrm{l}$ of MTT solution ( $5 \mathrm{mg} / \mathrm{ml}$ MTT in PBS) was added to each well and the 96-well plates were returned to the $\mathrm{CO}_{2}$ incubator for 1 hour. The MTT-containing medium was removed. The blue formazan product formed by the reduction in live attached cells was dissolved by adding $100 \mu \mathrm{l}$ of $100 \%$ DMSO per well after removal of the MTTcontaining medium. The plates were swirled gently at room temperature for 10 minutes to dissolve the precipitate. Absorbance was monitored at $540 \mathrm{~nm}$ in a Labsystems iEMS Reader MF (Labsystems Oy, Helsinki, Finland) using the DeltaSoft II v.4.14 software (Biometallics Inc., Princeton, NJ, USA). Dose-response curves were drawn based on the $\%$ of the control in Excel. The $\mathrm{IC}_{50}$ was deduced from the curves.

\section{Acknowledgement}

The financial support from The Swedish International Development Agency (SIDA) in a bilateral collaboration between Lund University (Sweden) and San Simon University (Bolivia) is fully acknowledged. We also wish to thank to Dr. Karl-Erik Bergquist for his helpful comments on the manuscript.

\section{Supporting Information}

Supporting information containing the ${ }^{1} \mathrm{H}-\mathrm{NMR}$ and ${ }^{13} \mathrm{C}-\mathrm{NMR}$ spectra of compounds $\mathbf{3}$ and $\mathbf{8}$ are available in the online version (Type: PDF, Size: ca. $0.1 \mathrm{MB}$ ): http://dx.doi.org/10.3797/scipharm.1310-18. 


\section{Authors' Statement}

The authors declare no conflict of interest.

\section{References}

[1] King RM, Robinson $\mathrm{H}$.

Studies in the Eupatorieae (Asteraceae). CCII. A new genus Kaunia.

Phytologia. 1980; 47: 257-260.

[2] Ulloa C, Jørgensen PM.

Arboles y arbustos de los Andes del Ecuador.

AAU Reports. 1993; 30: 1-264.

[3] Bohlmann F, Trinks C, Jakupovic J, King RM, Robinson H.

A further guaianolide from Kaunia arbuscularis.

Planta Med. 1984; 50: 284.

http://dx.doi.org/10.1055/s-2007-969708

[4] Bohlmann F, Kramp W, Gupta RK, King RM, Robinson H.

Four guaianolides and other constituents from three Kaunia Species.

Phytochemistry. 1981; 20: 2375-2378.

http://dx.doi.org/10.1016/S0031-9422(00)82669-2

[5] Rücker G, Schenkel EP, Mayer R, Hausen BM.

Allergenic sesquiterpene lactones from Eupatorium cannabinum $L$. and Kaunia rufescens (Lund ex de Candolle).

Natural Toxins. 1997; 5: 223-227.

http://dx.doi.org/10.1002/(SICl)1522-7189(1997)5:6<223::AID-NT1>3.0.CO;2-R

[6] De Gutierrez A, Sigstad EE, Catalan CA, Gutierrez AB, Herz W.

Guaianolides from Kaunia lasiophthalma.

Phytochemistry. 1990; 29: 1219-1225.

http://dx.doi.org/10.1016/0031-9422(90)85432-F

[7] Johansson $\mathrm{MH}$.

Reversible Michael additions: covalent inhibitors and prodrugs.

Mini Rev Med Chem. 2012; 12: 1330-1344.

http://dx.doi.org/10.2174/13895575112091330

[8] Sørlie T, Perou CM, Tibshirani R, Aas T, Geisler S, Johnsen H, Hastie T, Eisen MB, van de Rijn M, Jeffrey SS, Thorsen T, Quist H, Matese JC, Brown PO, Botstein D, Lønning PE, Børresen-Dale AL. Gene expression patterns of breast carcinomas distinguish tumor subclasses with clinical implications. Proc Natl Acad Sci U S A. 2001; 98: 10869-10874.

http://dx.doi.org/10.1073/pnas.191367098

[9] Sorlie T, Tibshirani R, Parker J, Hastie T, Marron JS, Nobel A, Deng S, Johnsen H, Pesich R, Geisler S, Demeter J, Perou CM, Lønning PE, Brown PO, Børresen-Dale AL, Botstein D.

Repeated observation of breast tumor subtypes in independent gene expression data sets.

Proc Natl Acad Sci U S A. 2003; 100: 8418-8423.

http://dx.doi.org/10.1073/pnas.0932692100

[10] Perou CM, Jeffrey SS, van de Rijn M, Rees CA, Eisen MB, Ross DT, Pergamenschikov A, Williams CF, Zhu SX, Lee JC, Lashkari D, Shalon D, Brown PO, Botstein D.

Distinctive gene expression patterns in human mammary epithelial cells and breast cancers.

Proc Natl Acad Sci U S A. 1999; 96: 9212-9217.

http://dx.doi.org/10.1073/pnas.96.16.9212 
[11] Jönsson G, Staaf J, Olsson E, Heidenblad M, Vallon-Christersson J, Osoegawa K, de Jong P, Oredsson S, Ringnér M, Höglund M, Borg A.

High-resolution genomic profiles of breast cancer cell lines assessed by tiling BAC array comparative genomic hybridization.

Genes Chromosomes Cancer. 2007; 46: 543-558.

http://dx.doi.org/10.1002/gcc.20438

[12] Perou CM, Sørlie T, Eisen MB, van de Rijn M, Jeffrey SS, Rees CA, Pollack JR, Ross DT, Johnsen H, Akslen LA, Fluge O, Pergamenschikov A, Williams C, Zhu SX, Lønning PE, Børresen-Dale AL, Brown PO, Botstein D.

Molecular portraits of human breast tumours.

Nature. 2000; 406:747-752.

http://dx.doi.org/10.1038/35021093

[13] Hu Z, Fan C, Oh DS, Marron JS, He X, Qaqish BF, Livasy C, Carey LA, Reynolds E, Dressler L, Nobel A, Parker J, Ewend MG, Sawyer LR, Wu J, Liu Y, Nanda R, Tretiakova M, Ruiz Orrico A, Dreher D, Palazzo JP, Perreard L, Nelson E, Mone M, Hansen H, Mullins M, Quackenbush JF, Ellis MJ, Olopade OI, Bernard PS, Perou CM.

The molecular portraits of breast tumors are conserved across microarray platforms.

BMC Genomics, 2006; 7: 96.

http://dx.doi.org/10.1186/1471-2164-7-96

[14] El-Feraly FS, Benigni DA.

Sesquiterpene lactones of Laurus nobilis leaves.

J Nat Prod. 1980; 43: 527-531.

http://dx.doi.org/10.1021/np50010a016

[15] Kisiel W.

A new germacranolide from Zinnia haageana.

Phytochemistry. 1978; 17: 1059-1060.

http://dx.doi.org/10.1016/S0031-9422(00)94281-X

[16] Sanz JF, Marco JA.

NMR studies of tatridin A and some related sesquiterpene lactones from Tanacetum vulgare.

J Nat Prod. 1991; 54: 91-96.

http://dx.doi.org/10.1021/np50074a040

[17] Julianti E, Jang K, Lee S, Lee D, Mar W, Oh K-B, Shin J.

Sesquiterpenes from the leaves of Laurus nobilis $L$.

Phytochemistry. 2012; 80: 70-76.

http://dx.doi.org/10.1016/j.phytochem.2012.05.013

[18] Appendino G, Belliardo F, Nano GM, Stefenelli S.

Sesquiterpene lactones from Artemisia genipi Weber: isolation and determination in plant material and in liqueurs.

J Agric Food Chem. 1982; 30: 518-521.

http://dx.doi.org/10.1021/jf00111a027

[19] Bohlmann F, Jakupovic J, Ahmed M, Schuster A.

Sesquiterpene lactones and other constituents from Schistostephium species.

Phytochemistry. 1983; 22: 1623-1636.

http://dx.doi.org/10.1016/0031-9422(83)80100-9

[20] Romo de Vivar A, Jimenez H.

Structure of santamarine, a new sesquiterpene lactone.

Tetrahedron. 1965; 21: 1741-1745.

http://dx.doi.org/10.1016/S0040-4020(01)98644-2

[21] Romo J, Romo de Vivar A, Trevino R, Joseph-Nathan P, Diaz E.

Constituents of Artemisia and Chrysanthemum species. Structures of chrysartemins A and B.

Phytochemistry. 1970; 9: 1615-1621.

http://dx.doi.org/10.1016/S0031-9422(00)85285-1 
[22] Mata R, Delgado G, Romo de Vivar A.

Sesquiterpene lactones of Artemisia mexicana var. Angustifolia.

Phytochemistry. 1984; 23: 1665-1668.

http://dx.doi.org/10.1016/S0031-9422(00)83464-0

[23] Bhadane NR, Kelsey RG, Shafizadeh F.

Sesquiterpene lactones of Artemisia tridentata ssp. Vaseyana.

Phytochemistry. 1975; 14: 2084-2085.

http://dx.doi.org/10.1016/0031-9422(75)83134-7

[24] Matsuda H, Uemura T, Shimoda H, Ninomiya K, Yoshikawa M, Kawahara Y.

Anti-alcoholism active constituents from Laurel and Linden.

Tennen Yuki Kagobutsu Toronkai Koen Yoshishu, 2000; 42: 469-474.

[25] Herz W, Sumi Y.

Constituents of Ambrosia and related species. III. Constituents of Ambrosia hispida.

J Org Chem. 1964; 29: 3438-3439.

http://dx.doi.org/10.1021/j001034a526

[26] Rao MM, Kingston DG, Spittler TD.

Flavonoids from Flourensia cernua.

Phytochemistry. 1970; 9: 227-228.

http://dx.doi.org/10.1016/S0031-9422(00)86634-0

[27] Ulubelen A, Miski M, Neuman P, Mabry TJ.

Flavonoids of Salvia tomentosa (Labiatae).

J Nat Prod. 1979; 42: 261-263.

http://dx.doi.org/10.1021/np50003a002

[28] Kupchan SM, Sigel C, Hemingway RJ, Knox JR, Udayamurthy MS.

Tumor inhibitors-XXXIII : Cytotoxic flavones from eupatorium species.

Tetrahedron. 1969; 25: 1603-1615.

http://dx.doi.org/10.1016/S0040-4020(01)82733-2

[29] Jakupovic J, Aal MA, Eid F, El-Dahmy S, Sarg T.

Further glaucolides and other sesquiterpene lactones from Brocchia cinerea.

Phytochemistry. 1988; 27: 2219-2224.

http://dx.doi.org/10.1016/0031-9422(88)80130-4

[30] Li T-S, Li J-T, LiH-Z.

Modified and convenient preparation of silica impregnated with silver nitrate and its application to the separation of steroids and triterpenes.

J Chromatogr. 1995; 715: 372-375.

http://dx.doi.org/10.1016/0021-9673(95)00619-X

[31] Ruprah PK, Cros J-P, Pease JE, Whittingham W, Williams J.

Studies towards the total synthesis of cycloaraneosene and ophiobolin M: a general strategy for the construction of the 5-8 bicyclic ring system.

Eur J Org Chem. 2002; 2002: 3145-3152.

http://dx.doi.org/10.1002/1099-0690(200209)2002:18<3145::AID-EJOC3145>3.0.CO;2-3

[32] Johannsson OT, Staff S, Vallon-Christersson J, Kytöla S, Gudjonsson T, Rennstam K, Hedenfalk IA, Adeyinka A, Kjellén E, Wennerberg J, Baldetorp B, Petersen OW, Olsson H, Oredsson S, Isola J, Borg A.

Characterization of a novel breast carcinoma xenograft and cell line derived from a BRCA1 germ-line mutation carrier.

Lab Invest. 2003; 83: 387-396.

http://www.ncbi.nlm.nih.gov/pubmed/12649339 
[33] Holst CM, Staaf J, Joensson G, Hegardt C, Oredsson SM.

Molecular mechanisms underlying N1, N11-diethylnorspermine-induced apoptosis in a human breast cancer cell line.

Anticancer Drugs. 2008; 19: 871-883.

http://dx.doi.org/10.1097/CAD.0b013e32830f902b

[34] Holst CM, Oredsson SM.

Comparison of three cytotoxicity tests in the evaluation of the cytotoxicity of a spermine analogue on human breast cancer cell lines.

Toxicol In Vitro, 2005; 19: 379-387.

http://dx.doi.org/10.1016/j.tiv.2004.10.005 